\title{
SUGGESTED YANOMAMI / YANOMAMÖ FILMS
}

The Feast (1970, 29 minutes) Yanomamö feasts are more than ceremonial events. They also have important economic and political implications. In this film one village (Patanowä-teri) invites another (Mahekoto-teri) to a feast to renew an old alliance in the hope of then attacking a third village. The Feast won first prize in every film competition in which it was entered. Patrick Tierney asserts the film was staged.

Magical Death (1973, 28 minutes) A study of a Yanomamö shaman in action. Dedeheiwä and a fellow shaman from Mishimishimaböwei-teri conduct two days of rituals in which, through speaking with hekura, or spirits, they seek to kill a man from another village. The film's depiction of Yanomamö shamans under the influence of hallucinogenic drugs, with green mucus dripping from their nostrils is graphic. Tierney writes of the film that Timothy Asch (who coproduced many of the Yanomamö films with Chagnon) "begged Chagnon to remove it [the film] from circulation because he had found that his students at USC [University of Southern California] were horrified by the Yanomami's symbolic cannibalism. ... Chagnon attributed this to jealousy on Asch's part; . . . Chagnon had made the film all by himself, and it won a blue ribbon at the American Film Festival" (2000:II2-I3).

A Man Called Bee: Studying the Yanomamö (1974, 40 minutes) Provides a sense of an anthropologist (Napoleon Chagnon) at work in the field: his entering a village adorned with feathers, sharing coffee with Dedeheiwä, offering medical help to a baby, and collecting genealogies. The commentary helps viewers understand the problems faced in working in this setting (including the problem Chagnon faced in collecting genealogies).

The Ax Fight (1975, 30 minutes) Discusses an escalating conflict between members of Mishimishimaböwei-teri and guests from another village (who had once belonged to Mishimishimaböwei-teri). The film is divided into four parts: an unedited version that shows what was observed by the camera, an explanation by Chagnon of what transpired, a discussion of the kin relations among the individuals involved, and, finally, a coherent, edited version of the conflict. The film conveys how ethnographic filmmaking, like ethnography, strives to bring coherence out of confusion in making sense of such events. Napoleon Chagnon discusses the contexts surrounding the filming, as well 
as his strained relationship with Tim Asch, at the Web page "Ethnographic and Personal Aspects of Filming and Producing The Ax Fight" (http://www .anth.ucsb.edu/projects/axfight/updates/filming.html) and in the CD-ROM "Yanomamö Interactive: The Ax Fight."

Warriors of the Amazon (I996, 56 minutes) Produced by Andy Jillings (for NOVA/BBC), the film portrays a feast that seeks to bring together two formerly opposed villages to form a new alliance. Most of the film was apparently staged, but it presents in vivid terms an event that was not: the death and cremation of a young mother and her child. Most problematic is why the film crew allowed the young mother to die without offering medical assistance. In the preliminary report of the El Dorado Task Force, Jane Hill writes: "It would have been easy to take the woman, who is quite young, perhaps even still a teenager, to the hospital" (AAA 200Ib:I8). She continues "There is a grim lesson here for us all: decent ordinary people, in the grip of a racializing representation that the film reproduces in almost every dimension, can behave in ways that deeply shocked members of the Task Force . . . and that must have been a dehumanizing experience for the Yanomami” (I9). 